\title{
Gehoord worden
}

\author{
HUGO VAN WAARDE \\ adjunct-hoofdredacteur
}

$\mathrm{I}$ $k$ ben opgegroeid aan zee, op een van de Zuid-Hollandse eilanden. Een prachtige plek daar niet van, maar met de puberteit in zicht werd het me er toch wat te benauwd. Alle regels en beperkingen over wat wel mocht en wat niet, begonnen al snel te knellen. Mijn ouders waren lid van een kerkgenootschap waar ik vooral van onthouden heb dat er veel was dat niet mocht. Trouw aan wat een rechtgeaarde puber behoort te doen, ging ik me daar stevig tegen verzetten. Mijn ouders begrepen er niets van en probeerden me op andere gedachten te brengen. Zonder succes. Op mijn zestiende ging ik het huis uit en begon mijn loopbaan in de verpleging. Of het uit die tijd stamt weet ik niet, maar een beperking van mijn vrijheden roept bij mij nog steeds verzet op. Met dat gevoel heb ik dan ook gekeken naar het - ogenschijnlijke gemak waarmee tal van ouderen zich lieten opsluiten in zorginstellingen en/ of zich essentieel menselijk contact met hun dierbaren lieten onthouden. Alles om een eventuele besmetting met COVID-19 te voorkomen, $\mathrm{u}$ heeft het zelf allemaal in uw praktijk meegemaakt. Maar is gezondheid belangrijker dan menselijk contact wanneer je op leeftijd bent? Wat was eigenlijk de impact van het gemis aan contact met hun dierbaren op onze ouderen? Hoe hebben medewerkers dit ervaren? In dit nummer van Denkbeeld lopen deze vragen door de meeste bijdragen heen.

Neem nu de ervaringen van verpleegkundige Saskia Jelten, iemand die

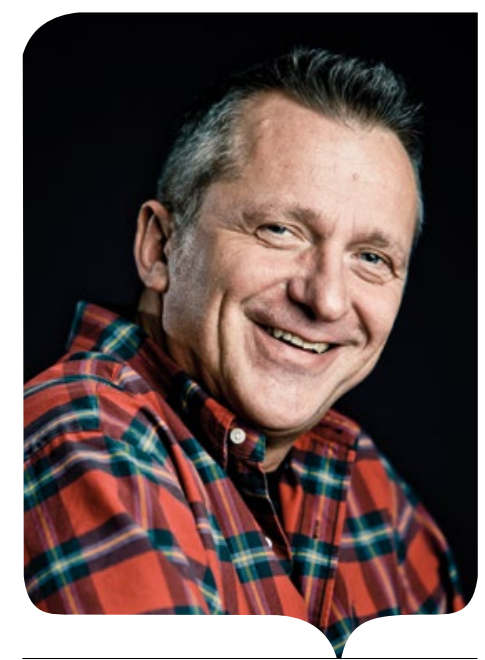

ᄎ Hugo van Waarde is adjuncthoofdredacteur van Denkbeeld; hij is zelfstandig werkzaam als adviseur en trainer in de zorg voor mensen met dementie.

overtuigd is van het belang van familiebetrokkenheid in het verpleeghuis. In 'COVID-19. Een persoonlijk relaas' beschrijft ze hoe ze voortdurend lastige keuzes moest maken toen bewoners ziek werden. En dan niet alleen tussen veiligheid en kwaliteit van leven voor de bewoners, maar ook voor zichzelf en haar gezin..Wanneer.je vrij bent, bekruipt je bijna het gevoel dat het niet ethisch is om te ontspannen en dat je hoort te werken. Maar wanneer je extra werkt, word je overvallen door de gedachte dat je eigenlijk thuis moet zijn.' Dat medewerkers in de zorg het zwaar hadden en dat er dringend ondersteuning nodig was, zagen Marion Klaver en Claire Thorn, beiden psycholoog, heel goed. In het artikel 'Zorg voor de zorg' beschrijven zij wat ze gedaan hebben om zorgteams te ondersteunen.

Journalist Dieuwke de Boer interviewde casemanager Lies Orthman en verpleegkundige Teun Toebes, beiden lid van de redactie van Denkbeeld. Ook zij hebben geworsteld met de beperkingen die vanuit de overheid werden en worden opgelegd en de dilemma's die daaruit voortvloeiden. Lies sluit naadloos aan bij mijn gevoelens van irritatie en verzet: 'Deze mensen hebben hun hele leven hard gewerkt en overleefden in sommige gevallen de Spaanse griep, de Tweede Wereldoorlog én de Watersnoodramp. Moeten ze dan het laatste deel van hun leven opgesloten zitten in hun eigen huis of in een verpleeghuis? Daar mogen ze zelf toch ook iets van vinden?'

Deze ervaringen van zorgverleners 'uit de frontlinie' zijn heel herkenbaar en raken mij als 'oude rot' in het hart. Ik hoop dat hun boodschap veel lezers zal bereiken en ik gun iedereen die afhankelijk is en zorg nodig heeft, hulpverleners als Saskia, Marion, Claire, Lies en Teun. En al die anderen die anoniem blijven... 